vidual for a whole year, have applied for permission to work there. Last year Mr. Whitman, whose observations on the development of Clepsine are well known, received this permission under special cireumstances by the courtesy of the staff, and carried out some excellent researches on Dicæmidæ, which are published in the last number of the Mittheilungen. Recently an increased number of similar applications have been received from American zoologists.

In speaking of the arrangements of the station, the perfection of the organisation for the supply of material, by means of the dredging and fishing of the gulf, cannot be too warmly praised or admired. Except in continuously bad weather, the beautiful and wonderful creatures comprising the rich Mediterranean fauna are brought in to the station in an abundance that is perfectly bewildering to a zoologist on his first visit. The possession of two steam launches, the larger of which, the Johannes Müller, was given by the Berlin Academy in 1877 , while the smaller was purchased subsequently, gives to the fishing department the facilities for rapid locomotion and transport, without which such abundance and perfect condition of the living material could not be obtained; especially as some of the most fruitful localities are widely separated, and a great many of the creatures, including all pelagic forms, are of extreme sensitiveness and delicacy.

The zoological station, although only nine years have passed since its first opening, has become a necessity for the progress of zoology; its international character enables every country to contribute to its support and share in the benefits derived from it ; it is a great organisation by which forces of various kinds are brought together to aid in the attainment of one great object, the investigation of the facts and phenomena of marine life in all its diversities, and their explanation in accordance with the principles of evolution. The progress which is brought about by the work actuallydone in the station is not more important than the indirect influence it exerts in various ways; its example has produced similar enterprises in various parts of the world; the benefit of the experience it gains extends to other centres of scientific research, and other branches of biology than marine zoology, and by its own vitality and its influence on the zoologists who study at its tables it has done much to sustain and develop the great impulse which the genius of Darwin gave to zoology twenty-three years ago.

J. T. CunNingham

\section{EPPING FOREST}

$\prod$ He $\mathrm{HE}$ House of Commons divided last Monday afternoon upon the Chingford and High Beech Railway Bill. An amendment was proposed by Mr. Bryce, Chairman of the Commons Preservation Society, and was supported by Mr. Thorold Rogers, Sir H. J. Selwin-Ibbetson, who framed the Epping Forest Act of I878, Mr. Fowler, Mr. Firth, Mr. T. C. Baring, Lord Eustace Cecil, Mr. Ritchie, Mr. James, Mr. Caine, and Mr. Waddy. As a fitting sequel to Mr. Meldola's paper, which we published last week, the result of the division, which was announced amidst cheers, was : For the second reading, 82 ; against it, 230 ; majority against the Bill, 148. It is to be hoped that this will be the last attempt to tamper with what Mr. Bryce justly described as " a priceless heritage of the people of London."
It is inevitable from the growth of our great towns that the student of Nature dwelling in their midst must go farther and farther afield for the objects of his study. It seems, moreover, that our science is at present inadequate to prevent the lethal influence of smoke and acrid fumes from dealing destruction to vegetation over a wide region outside the actual boundaries of these towns. The sanitary necessity of open spaces has been amply demonstrated ; but it was not as a mere open space or people's park that Parliament allowed the Corporation of London to acquire Epping Forest in 1878 .

The so-called rights of those who had inclosed the Forest, were overridden in order that an expanse of natural and, in some senses, primeval forest might be secured for the benefit of all classes of the public free from encroachment for ever. Parliament directed that it was to be preserved "in its natural condition as a forest," and conferred upon a Committee-composed of some members of that Corporation which holds the manorial rights, together with four resident gentlemen as Verderers, elected nominally by the commoners-the position of Conservators.

Unfortunately Common Councilmen seem to share the popular ignorance as to what constitutes the natural aspect of a forest. Many people believe a forest to be a large wood or plantation, and the Conservators seem to have been mainly actuated by fears lest visitors should get their feet wet or find the Forest less amusing than other suburban resorts. Draining and roadmaking have been their main tasks with a view to maintain the natural aspect the Forest wore for centuries, while during the five years they have been in office no attempt has been made at reafforesting the now unsightly fallows that the intruders had reduced into an arable condition. Pieces of artificial water have been constructed, mostly with outlines reminding one of the so-called Round Pond in Kensington Gardens ; pleasure-boats have been licensed upon them at a rental estimated at over $200 l$. per annum; free displays of fireworks in connection with a huge tavern, shooting-galleries, and steam-roundabouts have been authorised as contributing to a truly ideal forest.

These steps have of course been taken with the idea that the Conservators had the power to act in the way they think best calculated to elevate and refine the working-classes; but they are diametrically opposed to the spirit of the Act of 1878 , which did not aim at establishing a tea-garden or at pandering to the lowest tastes of any class of the community.

As is seen from Mr. Meldola's article, the Essex Field Club and other scientific societies have more than once protested against such mismanagement; but the Conservators had not yet filled up the full measure of their iniquities. They must promote a railway, if not a tramway as well.

Erglish public opinion is beginning to awaken to the idea that we have now almost as many railways as are required for any purposes but providing fees for directors and engineers and feeding the jealousies of rival companies. In the present session of Parliament the railway companies have evinced in the 'Bills they are promoting a partiality for common land that would be remarkable were not the reason for it sufficiently obvious. Common land can be had cheap; for it is everybody's business to 
oppose its spoliation, and everybody's business is proverbially nobody's. It is to be hoped, however, that the knell of these schemes was sounded on Monday last, when the House of Commons, on the motion of leading men of both parties, rejected the Chingford and High Beech Extension Bill, promoted by the Corporation and the Great Eastern Railway, by an overwhelming majority.

The House was fully aware that the line then proposed by Sir Thomas Chambers and Lord Claud Hamilton was only the first section of a longer one which would ultimately surround the Forest, and that it was intended to serve at first mainly as a feeder to another large tavern. All lovers of nature will rejoice that the collecting ground of Edward Forster, the Doubledays, and thousands of London naturalists less known to fame, has been reseued from destruction.

Authorities inform us that lopping and smoke have reduced the number of lichens and insects even during the last twenty years, and Conservatorial draining may have a similar effect upon other groups of organisms, so that the help of a railway in the work of devastation is certainly not required.

It is to be hoped that the verdict of Parliament will show the Conservators that forest management has a scientific basis and that their powers are not unlimited. It is equally desirable that the public interested in the Forest will form some organisation for its protection from encroachment and mismanagement in the future, so as to relieve a scientific body such as the Essex Field Club, which has borne the chief labour of opposition, from a task which, from its political and litigious character, must necessarily be uncongenial.

\section{G. S. BOULGER}

\section{PERRY'S "PRACTICAL MECHANICS" \\ Practical Mechanics. By John Perry, M.E. (London : Cassell, Petter, and Galpin, I883.)}

THIS book is one of a series of manuals now being published by Messrs. Cassell and Co., intended for the use of technical students, and claims, to quote the preface, "to put before non-mathematical readers a method of studying mechanics,', which, if carefully followed, will supply "a mental training of a kind not inferior to that the belief in which retains in our schools the study of ancient classics and Euclid." A principal feature of the method consists in "proving" the various formulæ of mechanics by quantitative experiments. Of these many are described in the book, several of which, such as those relating to torsion and other stresses, \&c., are carried on in many physical laboratories, and belong rather to physics than to mechanics. Another feature of the method more novel than the last is the gathering together of a few of the definitions and elementary theorems of mechanics, such as the parallelogram of forces, in a chapter at the end of the book called a glossary. Even then no formal proofs are given, probably because they are unnecessary, since on p. 2 we are told that the reader "cannot know the parallelogram of forces till he has proved the truth of the law half a dozen times experimentally with his own hands."

This kind of proof is very different from the evidence usually tendered for the fundamental laws of mechanics, but we must not forget the class of readers, entirely different as they seem to be from any we have ever encountered, for whom the book is intended. We are reminded of this on p. vii., when we are told that "the standpoint of an experienced workman in the nineteenth century is very different from that of an Alexandrian philosopher or of an English schoolboy, and many men who energetically begin the study of Euclid give it up after a year or two in disgust, because at the end they have only arrived at results which they knew exferimentally long ago."

Thus the empire of the Greeks in geometry must give place to the supremacy of the intelligence of the working man, and even Euclid himself must fall from his high estate to be compared and contrasted with the modern schoolboy. But this latest born of time apparently possesses even bigher powers. If made "to work in wood and metal," "to gain experience in the use of machines and use drawing instruments and scales," he will arrive at a condition in which "he may regard the $47^{\text {th }}$ proposition of the First Book of Euclid as axiomatic," and "he may think the important propositions in the Sixth Book as easy to believe in as those in the First." Truly here at last has been found in geometry a royal road. But when Prof. Perry has raised our opinion of the modern schoolboy and working man to this high eminence we feel a rude shock on reading the second page of the book, when we discover that these rarely gifted, ideal beings, so favoured of the gods in geometry, may perhaps not be able to apply to a practical example a simple algebraical rule.

In reading the book, especially in its earlier chapters, we are struck by the want of logical arrangement and of strictness in the definitions, by the frequent use of terms which have not been previously defined, or not adequately defined, and of writing so careless in its style as frequently to become unintelligible. The theory of friction, in the limited extent to which alone it is given, is inserted piecemeal into parts of the two first chapters and into the glossary, and the ordinary laws are not explicitly given until nearly the end of the book, but in their place we have the loose statements, "friction is proportional to load," and "friction is a passive force, which always helps the weaker to produce a balance." The English of the last sentence is as curious in character as that of one on p. I3, "This rubbing is a very slow motion."

The doctrine of the conservation of energy or of the conversion of energy into heat is nowhere explicitly given, although the theory is assumed in numerous applications. Can it be that the modern schoolboy, duly equipped, is able not only to surpass Pythagoras by regarding the $47^{\text {th }}$ proposition of Euclid as axiomatic, but that he has come to view the great physical theory as equally selfevident? It must be so; otherwise, having only been told of energy as the equivalent of mechanical work (p. 5), he would not understand the meaning of the obscure sentence- "Every experiment we can make shows that energy is indestructible, and consequently, if I give energy to a machine, and find that none remains in it, it must all have been given out by the machine."

We find the leading laws of hydrostatics inserted in a paragraph on water, which is included in the chapter on materials, fifty pages after the uniform transmission of fluid pressure has been assumed in the article on the 